\title{
Views of Academic Staff on Physical Education and Sports Teaching Undergraduate Program
}

\author{
Berna Karakoc ${ }^{1}$ \\ ${ }^{1}$ Physical Education and Sports Academy, Kilis 7 Aralik University, Kilis, Turkey \\ Correspondence: Berna Karakoc, Physical Education and Sports Academy, Kilis 7 Aralik University, Kilis, \\ Turkey.
}

Received: June 18, 2021

Accepted: July 25, $2021 \quad$ Online Published: September 8, 2021

doi:10.5539/ies.v14n10p28

URL: https://doi.org/10.5539/ies.v14n10p28

\begin{abstract}
The general purpose of this study is to find out the views of academic staff working in schools of Physical Education and Sports or faculties of Sports Sciences regarding the physical education and sports teaching undergraduate program. While finding out the views of academic staff, the physical education and sports teaching undergraduate program was examined within 5 different themes under the titles of general evaluation of the program, evaluation of the learning-teaching process, advantages of the program, disadvantages of the program and recommendations relating to the program. Under the theme general evaluation of the program, 4 different sub-themes were examined separately as evaluation of applied courses, evaluation of courses on teaching profession, evaluation of courses on content knowledge and evaluation of general culture and elective courses. The most frequently used qualitative research method, interview technique, was used in the study. A total of 12 academic staff were interviewed. The interviews were voice recorded and transcribed. The transcribed data were evaluated with descriptive analysis method and coded. Interpretations were made by using codes. As a result in general the academic staff stated their views the need to increase the number of applied courses, opening new applied courses, increasing the number of field-specific theoretical courses and updating the program and also their views that vocational courses were sufficient and physical infrastructure was insufficient.
\end{abstract}

Keywords: physical education, curriculum, undergraduate program, physical education and sports teaching curriculum

\section{Introduction}

Social, economic and technological developments of countries have affected their education system, and education systems which aim to educate qualified individuals aim for individuals who can solve problems on their own, who evolve, change and keep up with the world and who have high awareness (Naml1, 2018). As a qualified person, it is not possible for the characteristics we expect to have in an individual that we want to take part in the society from birth. It is clear that a good education is needed to gain these characteristics (Kara et al., 2017). It is possible to say that one of the elements that can provide this will be a well-planned training program. Countries have planned the human model they want to educate according to their philosophy and the needs of the society and prepared their teaching programs accordingly (Korkmaz, 2000; Özmen, 2004). In recent years, intensive studies have been carried out in our country in the field of education in order to adapt to changing conditions and teaching programs prepared with constructivist teaching approach have been put into practice throughout the country starting from 2005-2006 academic year (Bilir, 2008).

In teaching programs which aim to educate qualified individuals, there has to be teachers who continually renew and develop themselves as practitioners. If success is to be attained in education, the primary aim should be to train good teachers (Akpinar et al., 2004). Based on this, changes and arrangements are made not only in pre-school, primary education and secondary education, but also in higher education and these are thought as a whole and planned linked to each other (Sağlam et al., 2011) because in order to reach goals in education, education must be carried out in a planned and programmed way. In this process, reaching goals depends on teaching programs' being maintained appropriately by teachers (Büyükkaragöz \& Çivi, 1999). YÖK (The council of higher education) and the Ministry of National Education (MEB) work together to train good teachers in terms of both quality and quantity. It is a known fact that one of the most important factors affecting teacher quality is the courses offered in teaching departments of universities, the content and quality of programs, 
whether these programs are timely, and also the states of academic staff (Green, 2003; Spittle \& Spittle, 2016). As in all fields, the quality of the teacher who gives education in physical education and sports lessons also has an important place. For this reason, physical education and sports lessons have gained a very important place in the society. It is envisaged that the subjects in planning should be made according to needs in the society. Teaching plans are expected to include activities related with students' needs. In these plans, arrangements should be made for the developmental characteristics of individuals (Wuest \& Bucher, 1999; Capel, 2005; Tinning, 2006; Heper, 2012) and there should be harmony between the teaching program and the teacher for a healthy administration. This is because students, teachers of physical education and sports and prospective teachers studying in the departments of physical education and sports are influenced by the physical education programs cyclically (Titiz, 2005). Physical Education Programs should primarily focus on the learning of pre-service teachers. The content of the curriculum emphasizes students' learning to be physically active and in-depth teaching in physical activity. Events; Emphasize learning objectives that support motor skill competence, influencing performance quality and effectiveness, enjoying learning, as it leads to competitive sport and recreation opportunities (Clark, 2005; Ennis, 2010; Ennis, 2011).

Instead of each university preparing the physical education and sport teaching undergraduate program, the Council of Higher Education decided for a common program to be implemented (YÖK, 1998), then this was revised in 2006 (YÖK, 2007) and it is still being used today. Since 2006, although various changes were made in both primary education and secondary education physical education and sports teaching programs, it can be seen that undergraduate programs which train teachers to these programs have still not changed. In addition to the field knowledge they need to have, teachers of physical education also have a series of duties. They have undertaken tasks such as keeping students away from bad habits, guiding them and directing them to sports branches. Teachers of physical education and sport are important for fulfilling these duties. They lead the society to create a sports culture, to train healthy individuals, to make sure that students are introduced to sports, they are guided to sports and they advance in sports branches (Aktaş et al., 2021). In terms of the aforementioned issues, teachers of physical education and sports are not just the people who implement programs, they are also individuals who try to raise healthy societies. Since interaction is easier in terms of communication in physical education lessons, the program implemented is as important as the quality of teachers. Faculties of sports sciences, schools of physical education and sports and departments of physical education and sports teaching in faculties of education are responsible for training teachers of physical education and sports. It is important that council of higher education and ministry of national education work together and organize and update the program in terms of theoretical and applied courses.

In this study it was aimed to show the views of academic staff working in schools of physical education and sports or faculties of sport sciences at universities in different parts of Turkey on physical education and sports teaching undergraduate program, it was found that academic staff had different thoughts about physical education and sports teaching undergraduate program.

\section{Method}

Information was given about the research method, research group, data collection and data collection instrument in this section.

\subsection{Research Method}

Qualitative research method was used in the study. Qualitative research is one of the ways of producing knowledge developed by humans to solve their secrets and to explore the depths of the social systems they have shaped by their own efforts (Özdemir, 2010). Qualitative researchers use the language of events and context and they examine events within their context. They do not analyze problems by isolating them from the values system in which they are formed and developed, but they try to interpret the network of relationships that dominate the situations in their natural environment or try to reveal the meanings of these (Neuman, 2012). Interview technique, one of the most frequently used qualitative research methods, was used in the study and descriptive analysis technique was used to evaluate the data obtained. Descriptive analysis a type of qualitative data analysis that includes the summary and interpretation of data obtained with various data collection techniques according to predetermined themes. In this kind of analysis, the primary aim is to present the findings obtained to the reader in a summarized and interpreted way (Dawson, 2009).

\subsection{Research Group}

The research group of the study consisted of academic staff working in faculties of sports sciences or schools of physical education and sports at universities in various places of Turkey. Purposeful sampling method was used to determine the participants and the participants who were thought to have a rich knowledge on the subject content 
were assigned (Yıldırım \& Şimşek, 2013). For this purpose, the participants were chosen among the academic staff that could give the most suitable responses for the purposes of the study. In the study, a total of 12 academic staff were interviewed to examine the teaching program implemented in the departments of physical education and sports. Each academic staff was represented with a number, not with their names. For example number "1" represents the academic staff numbered 1.

Distribution of the academic staff who participated in the interviews in terms of some variables and information about each academic staff is given below in two different tables.

Table 1. Distribution of the academic staff who participated in the interviews in terms of some variables

\begin{tabular}{|c|c|c|c|}
\hline \multicolumn{2}{|c|}{ Variable } & Number & $\%$ \\
\hline \multirow{2}{*}{ Gender } & Female & 3 & 25 \\
\hline & Male & 9 & 75 \\
\hline \multirow{3}{*}{ Age } & $20-30$ & 2 & 17 \\
\hline & $31-40$ & 4 & 33 \\
\hline & $41-50$ & 6 & 50 \\
\hline \multirow{4}{*}{ Length of service } & 5-10 years & 2 & 17 \\
\hline & $11-15$ years & 4 & 33 \\
\hline & $16-20$ years & 4 & 33 \\
\hline & 21 years and more & 2 & 17 \\
\hline \multirow{4}{*}{ Title } & Lecturer & 1 & 8 \\
\hline & Assist. Prof. Dr. & 5 & 42 \\
\hline & Assoc. Prof. Dr & 4 & 33 \\
\hline & Prof. Dr. & 2 & 17 \\
\hline
\end{tabular}

In Table 1, it can be seen that of the 12 academic staff who participated in the study which was conducted to examine the teaching programs implemented in departments of physical education and sports, $9(75 \%)$ were male, while $3(25 \%)$ were female. In terms of the variable of age, it was found that 6 were $(50 \%)$ were between $41-50$ years of age, 6 were (33\%) were between 31-40 years of age and 2 (17\%) were between 20-30 years of age. In terms of the variable of length of service, it was found that $1(17 \%)$ had a length of service between 5 and 10 years, $4(33 \%)$ had a length of service between 11 and 15 years, $4(33 \%)$ had a length of service between 16 and 20 years, and lastly $2(17 \%)$ had a length of service of 21 years and more. When the participants were examined in terms of the variable of title, it was found that $1(8 \%)$ of the participants was a lecturer, $5(42 \%)$ were Assist. Prof. Dr., 4 (33\%) were Assoc. Prof. Dr. and 2 (17\%) were Prof. Dr.

Table 2. Information on the academic staff

\begin{tabular}{ccccc}
\hline Number & Gender & Age & Length of service & Title \\
\hline 1 & Female & 30 & $5-10$ years & Lecturer \\
2 & Male & 29 & $5-10$ years & Assist. Prof. Dr. \\
3 & Male & 38 & $11-15$ years & Assist. Prof. Dr. \\
4 & Female & 32 & $11-15$ years & Assist. Prof. Dr. \\
5 & Male & 41 & $11-15$ years & Assist. Prof. Dr. \\
6 & Male & 42 & $16-20$ years & Assist. Prof. Dr. \\
7 & Male & 40 & $16-20$ years & Assoc. Prof. Dr. \\
8 & Male & 35 & $11-15$ years & Assoc. Prof. Dr. \\
9 & Male & 41 & $16-20$ years & Assoc. Prof. Dr. \\
10 & Male & 42 & $16-20$ years & Assoc. Prof. Dr. \\
11 & Female & 45 & 21 years and longer & Prof. Dr. \\
12 & Male & 44 & 21 years and longer & Prof. Dr. \\
\hline
\end{tabular}

Table 2 included information regarding the gender, age, length of service and titles of the academic staff represented by numbers. 


\subsection{Data Collection Tool}

Data collection tool of the study consists of semi-structured interviews. Interviews are important since they are carried out according to a previously prepared interview protocol, they provide ease to the researcher and they present more systematic and comparable information (Berg, 2009; Power et al., 2010; Yıldırım and Şimsek, 2013). While preparing the interview questions used as data collection tool, first of all literature was reviewed. After the questions were drafted, they were listed as items. Next, expert opinion was taken and with the opinions of 3 experts, items were deleted and edited. The final version was examined by linguists and the interview questions were finalized. The following questions were asked to academic staff working in universities about the teaching programs implemented in departments of physical education and sports:

1) What are your views on physical education and sports teaching undergraduate program?

a) What are your views on applied courses in physical education and sports department?

b) What are your views on vocational courses in physical education and sports department?

c) What are your views on field education courses in physical education and sports department?

d) What are your views on general culture and elective courses in physical education and sports department?

2) What are your views on the teaching-learning process in physical education and sports undergraduate program?

3) What do you think are the advantages of physical education and sports undergraduate program?

4) What do you think are the disadvantages of physical education and sports undergraduate program?

5) What are the suggestions that you can make for physical education and sports undergraduate program?

In general, the interview included questions to evaluate physical education and sports undergraduate program. The answers to the questions were evaluated and 5 different themes were determined under the titles of general evaluation of the program, evaluation of the learning-teaching process, advantages of the program, disadvantages of the program and recommendations relating to the program. Under the theme general evaluation of the program, 4 different sub-themes were examined separately as evaluation of applied courses, evaluation of courses on teaching profession, evaluation of courses on content knowledge and evaluation of general culture and elective courses.

\subsection{Data Collection and Analysis}

The data collection tool of the study consists of semi-structured interviews with the academic staff. The interviews were made in January, 2021. Interviews were made separately with each participant by using semi-structured interview form prepared by the researcher. The academic staff participated in the interviews voluntarily and they stated that they would answer the questions sincerely. The interviews were voice recorded and the records were transcribed. The transcribed data were evaluated with descriptive analysis method. The codes formed as a result of the data obtained in descriptive analysis are placed under previously determined themes (Yıldırım \& Şimşek, 2013). The study also included frequency, which is the incidence of data. The codes formed were crosschecked by two researchers, the agreement between the codes was found as $88 \%$ and the study was considered to be reliable. Different codes were transformed into a common view and revised and a consensus was reached. Export opinion was taken about whether the questions meant the same thing by all the participants, whether the language used was plain and understandable and whether there were any problems with the interview form.

\section{Results}

In the analysis of qualitative data, the views of academic staff in the evaluation of physical education and sports teaching undergraduate program were arranged in a way that overlapped with the research questions. In general, tables were formed on themes, sub-themes, codes regarding the views of each academic staff and how many times the codes were mentioned. While finding out the views of academic staff on the undergraduate program, first of all the question "What are your views on physical education and sports teaching undergraduate program?" was asked. Table 3 includes the analysis of views of academic staff on "General Evaluation of the Program" theme. 
Table 3. Views of academic staff on "General Evaluation of the Program" theme

\begin{tabular}{|c|c|c|c|}
\hline Theme & \multicolumn{2}{|l|}{ Codes } & $\mathrm{F}$ \\
\hline & \multicolumn{2}{|l|}{ Applied courses should be increased } & 6 \\
\hline & \multicolumn{2}{|l|}{ Educational courses are predominant } & 4 \\
\hline & \multicolumn{2}{|c|}{ Core courses on sports should be both applied and theoretical } & 3 \\
\hline & \multicolumn{2}{|l|}{ Educational courses should be decreased } & 3 \\
\hline & \multicolumn{2}{|l|}{ Well-designed } & 2 \\
\hline General evaluation of the program & \multicolumn{2}{|l|}{ Immobile life style } & 2 \\
\hline & \multicolumn{2}{|l|}{ Disease } & 2 \\
\hline & \multicolumn{2}{|l|}{ Like the education faculty } & 1 \\
\hline & \multicolumn{2}{|c|}{ Equipping prospective teachers with new knowledge } & 1 \\
\hline & \multicolumn{2}{|l|}{ Name of the program should change } & 1 \\
\hline \multirow{33}{*}{$\begin{array}{l}\text { Sub-themes of General evaluation of } \\
\text { the program }\end{array}$} & \multirow{8}{*}{ Evaluation of applied courses } & Applied courses should be increased & 8 \\
\hline & & New courses should be introduced & 4 \\
\hline & & Educational courses are predominant & 4 \\
\hline & & $\begin{array}{l}\text { Courses on team and individual sports should be } \\
\text { increased }\end{array}$ & 3 \\
\hline & & $\begin{array}{l}\text { Field-specific theoretical courses should be } \\
\text { increased }\end{array}$ & 3 \\
\hline & & The number of main branches should be increased & 2 \\
\hline & & Students drift away from applied courses & 2 \\
\hline & & Successful athletes are restrained & 1 \\
\hline & \multirow{9}{*}{$\begin{array}{l}\text { Evaluation of courses on teaching } \\
\text { profession }\end{array}$} & Subject content courses should be increased & 7 \\
\hline & & The program should be updated & 4 \\
\hline & & Sufficient & 4 \\
\hline & & Useful in terms of the profession & 3 \\
\hline & & Educational courses are predominant & 3 \\
\hline & & The program is designed for KPSS & 2 \\
\hline & & Views of experts in the field should be taken & 2 \\
\hline & & KPSS field exam & 2 \\
\hline & & It does not contribute to Turkish sports & 1 \\
\hline & \multirow{10}{*}{$\begin{array}{l}\text { Evaluation of courses on content } \\
\text { knowledge }\end{array}$} & Field-specific courses should be increased & 4 \\
\hline & & Applied field courses should be increased & 4 \\
\hline & & Sport branches should be prioritized & 3 \\
\hline & & Theoretical knowledge should be increased & 3 \\
\hline & & It should be compulsory & 2 \\
\hline & & Sufficient & 2 \\
\hline & & Suitable for teaching program & 2 \\
\hline & & $\begin{array}{l}\text { Elective courses should be chosen according to } \\
\text { needs }\end{array}$ & 2 \\
\hline & & They should change each semester & 1 \\
\hline & & Standards should be set in applied courses & 1 \\
\hline & \multirow{6}{*}{$\begin{array}{l}\text { Evaluation of general culture and } \\
\text { elective courses }\end{array}$} & Sufficient & 7 \\
\hline & & $\begin{array}{l}\text { Should be taught by academic staff who are experts } \\
\text { in their field }\end{array}$ & 4 \\
\hline & & Not close to the structure of the program & 3 \\
\hline & & There should be enough courses & 2 \\
\hline & & Folk dance course should be compulsory & 2 \\
\hline & & Negative view & 2 \\
\hline
\end{tabular}

In Table 3, the first theme was determined as the general evaluation of the program and this theme was mentioned for 25 times in total. This theme includes codes relating the general evaluations of the academic staff on physical education and sports teaching program. Next the four sub-themes of general evaluation of the program were determined; and evaluation of applied courses was mentioned 27 times, evaluation of courses on 
teaching profession was mentioned 28 times, evaluation of courses on content knowledge was mentioned 24 times and evaluation of general culture and elective courses was mentioned 20 times. Below are some example expressions of academic staff's views on both general evaluation of the program and the sub-themes.

\subsection{General Evaluation of the Program}

I believe that students who start the program for the first time should receive core sport courses both as applied and as theoretical courses. (12)

In order to cope with immobile life style and diseases that develop with it, institutions which provide education about physical education and sports should equip prospective teachers with this information. (3)

Educational courses are predominant in physical education and sports teaching program, like the faculty of education. (5)

Within the scope of general evaluation of the program, academic staff predominantly shared their views on increasing the number of applied courses in the program and they specifically emphasized that core courses in the field of sports should be given both as applied and as theoretical courses and educational courses should be decreased.

\subsubsection{Evaluation of Applied Courses}

In this sub-theme, the academic staff were asked the question "What are your views on applied courses in physical education and sports department?" Below are some example expressions of academic staff's views on Evaluation of applied courses sub-theme.

The program is mainly based on educational courses. Therefore, students are drifting away from applied courses. (2)

Enough applied courses should be created with new regulations in this field. It will be useful to get the views of experts in the field in determining curriculum. (7)

The number of applied courses on branches is insufficient. Their numbers should be increased. (11)

While giving their views, most of the academic staff mentioned that the number of applied courses should be increased. They emphasized that new applied courses should be opened and the number of field-specific courses should be increased.

\subsubsection{Evaluation of Courses on Teaching Profession}

In this sub-theme, the academic staff was asked the question "What are your views on vocational courses in physical education and sports department?" Below are some example expressions of academic staff's views on evaluation of courses on teaching profession sub-theme.

There should be more courses on field knowledge. (6)

When we look at the curriculum, it can be seen that there are enough vocational courses and I believe that they will be useful for the profession when they are well imposed on the students. (9)

According to this program, only prospective teachers for KPSS will be educated. I don't think that any contributions will be made to Turkish sports. (12)

While giving their views, the academic staff emphasized that vocational courses are sufficient and it will be professionally more useful to update the program and to get the views of experts in the field.

\subsubsection{Evaluation of Courses on Content Knowledge}

In this sub-theme, the academic staff was asked the question "What are your views on field education courses in physical education and sports department?" Below are some example expressions of academic staff's views on field education courses sub-theme.

My views on field education courses in the new curriculum in physical education and sports teaching department are positive because they are suitable for the structure of physical education and sports teaching department. (1)

Both theoretical and applied courses should be focused on. (8)

There should be more field courses and elective courses should be selected by considering the needs of the age and field and ground standards of applied courses should be determined. (11)

While only a few of the academic staff thought that field courses were sufficient, in general the academic staff stated that field-specific courses and applied field courses should be increased. It was emphasized that sport branches should be prioritized and both compulsory and elective courses should change each semester. 


\subsubsection{Evaluation of General Culture and Elective Courses}

In this sub-theme, the academic staff was asked the question "What are your views on general culture and elective courses in physical education and sports department?" Below are some example expressions of academic staff's views on Evaluation of courses on general culture and elective courses sub-theme.

I think that the lessons we have are sufficient. (7)

It is negative. This is because I think that the general culture and elective courses in the new curriculum are far from the structure of physical education and sports teaching. (2)

Such courses should be in sufficient numbers each semester and they should be taught by academic staff who are experts in the field. (4)

While 7 of the academic staff thought that general culture and elective courses were sufficient, they stated that these courses had to be taught by experts in the field.

\subsection{Evaluation of the Learning-Teaching Process}

The table below includes the views of the academic staff on "Evaluation of the Learning-Teaching Process" theme.

Table 4. Views of the academic staff on "Evaluation of the Learning-Teaching Process" theme

\begin{tabular}{ll}
\hline Theme & Codes \\
\hline & The number and hours of theoretical courses should be decreased \\
& Insufficient physical infrastructure \\
& Field-specific courses should be increased \\
& Students should not be overloaded with theoretical knowledge \\
& Positive view \\
Evaluation of the learning-teaching process & There should be teaching practice and school experience courses every year \\
& Movement training course should be cancelled \\
& Differences in implementing the movement training course \\
& Unqualified graduates \\
& Making use of technology \\
1 & 1 \\
1
\end{tabular}

In Table 4, the second theme was determined as Evaluation of the learning-teaching process and this theme was mentioned for a total of 27 times. This theme includes codes relating the evaluation of the learning-teaching process of physical education and sports teaching program. In this context, some example statements of the academic staff are given below.

The adequacy of fields should be ensured and technology should be used more in this process relating the learning-teaching process. (10)

I believe that the hours and number of elective and compulsory courses in the teaching department should be decreased and taught without overloading students theoretically. (1)

While stating their views, academic staff stated that the number and hours of theoretical courses should be decreased, while field-specific ones should be increased. In addition, they also emphasized that physical infrastructure is insufficient and teaching practice and school experience courses should be taught each year.

\subsection{Advantages and Disadvantages of the Program}

The following table includes academic staff's views about the" Advantages and Disadvantages of the Program" theme. 
Table 5. Academic staff's views on the theme of "Advantages and Disadvantages of the Program"

\begin{tabular}{llr}
\hline Themes & Codes & $\mathrm{F}$ \\
\hline & Suitable for teaching program & 4 \\
& Different employment areas & 4 \\
& The prestige of teaching profession & 3 \\
& Ease of dress code & 3 \\
Advantages of the program & Chance to guide students & 2 \\
& Special service area & 2 \\
& Active life & 1 \\
& Contributions of applied courses to healthy life & 1 \\
\hline & Insufficient subject content courses & 7 \\
& Too many vocational courses & 5 \\
& Insufficient application areas & 4 \\
& Employment problem & 4 \\
& Inadequacy of graduates in their fields & 3 \\
& Double majoring & 1 \\
& The program's not being preferred & 1 \\
& Students' getting pedagogical formation from non-teaching areas & 1 \\
\hline
\end{tabular}

In Table 5, the third theme was determined as the advantages of the program and this theme was mentioned 20 times. The fourth theme was determined as the disadvantages of the program and this theme was mentioned 26 times. This theme includes codes relating to the advantages and disadvantages of physical education and sports teaching program. In this context, some example statements of the academic staff are given below.

\subsubsection{Advantages of the Program}

Apart from physical education and sports teaching, it also provides opportunities to work in different institutions such as police department, military and ministry of Youth and Sports. (8)

Teaching is a respectable profession and it guides students. (6)

In general, academic staff considers that physical education and sports teaching program is suitable for teaching profession. They mentioned some advantages such as different employment areas, ease of dress code and contributions to healthy life.

\subsubsection{Disadvantages of the Program}

The fact that the students in this program graduate without specializing in at least one branch and that there are insufficient practice areas are the disadvantages of this program. (12)

I think that the disadvantages are the fact that students who are in the program get only courses in teaching and do not have sufficient courses in the field of sports. (5)

In general, academic staff mentioned that there were few field-specific courses in physical education and sports teaching program, while there were too many vocational courses. Other disadvantages were students' being insufficient in their own fields due to the fact that there are few field-specific courses and insufficiency of existing practice areas.

\subsection{Suggestions About the Program}

The table below includes academic staff's "Suggestions about the Program" theme.

Table 6. Views of the academic staff on "Suggestions about the Program" theme

\begin{tabular}{lll}
\hline Themes & Codes & F \\
\hline \multirow{5}{*}{ Suggestions about the program } & Increasing applied courses & 8 \\
& Practical teaching of courses & 5 \\
& Updating the program & 5 \\
& Increasing sports facilities & 5 \\
& Getting views of experts & 3 \\
& Teaching field courses in detail & 3 \\
& Increasing use of technology & 2 \\
\hline
\end{tabular}


In Table 6, the fifth theme was determined as Suggestions about the program and this theme was mentioned 31 times. This theme includes codes relating the suggestions about physical training and sports teaching. In this context, some example statements of the academic staff are given below.

I believe that the program should be updated by getting help not only from educators but also from experts in the field of sports. (7)

Applied courses should be increased. (4)

In accordance with the program of Ministry of National Education, courses such as physical fitness, assessment and evaluation, movement training and educational games should be taught in detail. (9)

In general, the academic staff gave their views that the applied courses in physical education and sports teaching program should be increased in number. They also made suggestions that the program should be updated by getting views of experts in the field and courses should be taught in detail.

\section{Conclusion and Discussion}

The present study evaluated the views of academic staff working in universities about physical education and sports teaching program by using semi-structured interview questions. The views of academic staff were examined with 5 different themes under the titles of general evaluation of the program, evaluation of the learning-teaching process, advantages of the program, disadvantages of the program and recommendations relating to the program. Under the theme general evaluation of the program, and 4 different sub-themes as evaluation of applied courses, evaluation of courses on teaching profession, evaluation of courses on content knowledge and evaluation of general culture and elective courses. As a result of the analysis, many different conclusions were reached about the thoughts of academic staff relating physical education and sports teaching program.

According to the results of the study, many topics were found such as insufficient number of applied courses, too many vocational courses on teaching profession, opening new applied courses, the need to update the program, increasing team and individual sports courses, increasing the field-specific theoretical courses, courses being taught by academic staffs who are experts in the field. When the views of the lecturers about the general evaluation of the program are examined; they stated that the Physical Education and Sports program was well designed. This situation showed parallelism with the study conducted by Ha et al. (2004) in Hong Kong, and they stated that the program in practice in Hong Kong was successful and met the objectives. Another common views from the participants mentioned about the need to increase applied courses and content matter courses. In their study, Naml1 and Temel (2019) stated that there should also be applied courses in addition to theoretical courses. In a study conducted by Hill and Brodin (2004) on the perceptions of physical education and sports teachers about undergraduate courses, the result which showed that applied courses in physical education and sports teaching program were sufficient is not similar to the results of this study. The result of the present study that the number of team and individual sports should be increased is in parallel with the results of the study conducted by Korkmaz, Yavaş, Ercan, and Toker (1999) and it has also been stated that there is a need to enrich the teaching program put into practice in YÖK in terms of team sports and individual sports. As a result of analysing the views of academic staff, another result of the study is determining field-specific elective courses according to need. In a study conducted by Bulca et al. (2012), it was stated that Ministry of National Education teaching program should be considered while classifying elective courses. In parallel with the results of the study, in a study in which the institutions educating physical education teachers in Turkey were examined, Özkan (1999) concluded that teacher training programs should be organized in a way that includes various elective courses, by considering the needs of students in schools.

When the views of academic staff on learning teaching process were examined, it was found that they stated various views such as the insufficient number and hours of theoretical courses, insufficient physical infrastructure, the need to increase field-specific courses, having teaching practice and school experience courses each year. In their study they evaluated physical education and sports teaching undergraduate program, Namli and Temel (2019) interviewed teachers and the results which showed that teaching practice course was important, existing practices were insufficient and that these practices should occur much earlier were in parallel with the results of the present study. Similarly, in a study which evaluated teaching practices in education faculties, Aslan (2015) concluded that the hour of teaching course was insufficient.

When the views of academic staff regarding the advantages of the program were examined, it was found that the academic staff stated physical education and sports teaching program was prepared in accordance with teaching profession. Naml and Temel (2019) also reached a similar conclusion and stated that the program was in fact suitable for training teachers, while there were changes that had to be made. Pehlivan (2001) emphasized that the 
program aimed to train teachers for secondary education and it was designed accordingly.

When the views of academic staff regarding the advantages of the program were examined, it was found that the academic staff put forward various views such as courses on content matter and application areas were insufficient. Namli and Temel (2019)'s results that such as poor content, too much theoretical knowledge and insufficient special teaching methods course are in parallel with the present study.

When the suggestions of academic staff on the program were examined, it was found that they stated the need to increase the number of applied courses, to upgrade the program and to get the views of experts while preparing the program. Kaya (1999) stated in a study on the adequacy of course content that for a standard in teaching program, the program should be created as a result of the studies carried out by commissions including experts in the field. McPhail (2007) reached a similar conclusion in the study and stated that teachers who are experts in their fields want to be at the center of program planning and development studies.

\section{References}

Akpınar, B., Turan, M., \&Tekataş, H. (2004). Öğretmen adaylarının gözüyle sınıf öğretmenlerinin yeterlilikleri. XIII. Ulusal Eğitim Bilimleri Kurultayı, İnönü Üniversitesi, Malatya.

Aktaş, Ö., Karakoç, B., \& Karakoç, Ö. (2021). Analysis of Burnout Levels of Judo Coaches in the COVID-19 Period: Mixed Method. Journal of Educational Issues, 7(1), 469-486. https://doi.org/10.5296/jei.v7i1.18549

Aslan M. (2015). Eğitim Fakültelerindeki Öğretmenlik Uygulaması Dersinin Değerlendirilmesi ve Ö̆̆ $\neg$ retim Programının Hazırlanması. Eğitim Bilimleri Enstitüsü, Eğitim Bilimleri Anabilim Dalı, Doktora Tezi, Eskişehir: Anadolu Üniversitesi.

Berg, B. (2009). Qualitative Research Methods For The Social Sciences (7th ed.). Alliii and Bacon, Boston Ma.

Bilir, P. (2008). Yeni beden eğitimi öğretim programı ve köy enstitülerinde beden eğitimi derslerinin yapılandırmacı öğretim yaklaşımı açısından değerlendirilmesi. Spormetre Beden Eğitimi ve Spor Bilimleri Dergisi, 6(3), 145-150. https://doi.org/10.1501/Sporm_0000000107

Bulca, Y., Saçl1, F., Kangalgil, M., \& Demirhan, G. (2012). Beden eğitimi öğretmenlerinin öğretmen yetiştirme programına ilişkin görüşleri. Eğitim ve Bilim, 37(165).

Büyükkaragöz, S., \& Çivi, C. (1999). Genel Öğretim Metotları Öğretimde Planlama Uygulama. Beta Basım Yayın Dağıtım Yayın No:936, Ankara.

Capel, S. (2005). Teachers, teaching and pedagogy in physical education. Physical education: Essential issues, 111-127. https://doi.org/10.4135/9781446215876.n7

Clark, J. E. (2005). From the beginning: A developmental perspective on movement and mobility. Quest, 57, 37-45. https://doi.org/10.1080/00336297.2005.10491841

Dawson, C. (2009). Introduction to research methods: A practical guide for anyone undertaking a research project. Oxford: How to Books Ltd.

Ennis, C. D. (2010). On their own: Preparing students for a lifetime. Journal of Physical Education, Recreation \& Dance, 81(5), 17-22. https://doi.org/10.1080/07303084.2010.10598475

Ennis. C. D. (2011). Physical Education Curriculum Priorities: Evidence for Education and Skillfulness. Quest, 63(1), 5-18, https://doi.org/10.1080/00336297.2011.10483659

Green, K. (2003). Physical education teachers on physical education: A sociological study of philosophies and ideologies. Chester: Chester Academic Press.

Ha, A., Lee, J., Chan, D., \& Sum, R. (2004). Teachers' perceptions of in-service teacher training to support curriculum change in physical education: The Hong Kong experience. Sport, Education and Society, 9(3), 421-438. https://doi.org/10.1080/13573320412331302467

Heper, E. (2012). Sporla ilgili kavramlar ve sporun tarihsel gelişimi. Spor Bilimlerine Giriş (Ed.: Ertan H), Eskişehir: Anadolu Üniversitesi Yayınları (2509).

Hill, G., \& Brodin K. L. (2004). Physical Education Teachers' Perception of the Adequacy of University Course work in Preparation for Teaching. The Physical Educator, 61(2), 75-87.

Kara K., Karakoç B., Yıldırım İ., \& Bay E. (2017). Examination of "Curriculum Alignment" in the Context of Theory and Practice for the 8th Grade Mathematics Teaching. Harran Education Journal, 2(1), 26-40. https://doi.org/10.22596/2017.0201.26.40 
Kaya, Y. (1999). Beden Eğitimi ve Spor Yüksekokullarında/Bölümlerinde Okutulan Derslerin Ders İçe-riklerinin Yeterliği. Ulusal Beden Eğitimi ve Spor Öğretmenliği Lisans Programı Sempozyumu Bildiriler Kitabı, Uludağ Üniversitesi Basımevi, Bursa.

Korkmaz, İ. (2000). Öğretmen yetiştirmede yapısal ve kavramsal alternatifler. II. Ulusal Öğretmen Yetiştirme Sempozyumu, Çanakkale Onsekiz Mart Üniversitesi, Eğitim Fakültesi, 198-202.

Korkmaz, N. H., Yavaş, M., Ercan, İ., \&Toker, F. (1999). Uludağ Üniversitesi Eğitim Fakültesi Beden Eğitimi ve Spor Bölümü Öğretim Programlarıyla 1998 Yllindan İtibaren Uygulamaya Konulan Yükseköğretim Programının Karşılaştırılması. Ulusal Beden Eğitimi ve Spor Öğretmenliği Lisans Programı Sempozyumu Bildiriler Kitabı, Uludağ Üniversitesi Basımevi, Bursa.

MacPhail, A. (2007). Teachers' views on the construction, management and delivery ofan externally prescribedphysical education curriculum: Higher Grade Physical Education. Physical Education and Sport Pedagogy, 12(1), 43-60. https://doi.org/10.1080/17408980601060267

Namlı, A. K., \& Temel, C. (2019). Beden eğitimi ve spor öğretmenliği lisans programının değerlendirilmesi ve program önerisi. Milli Eğitim Dergisi, 48(1), 321-351.

Namlı, A. K. (2018). Beden ĕgitimi ve spor öğretmenliği lisans programının değerlendirilmesi. Yayımlanmamış Doktora Tezi. İnönü Üniversitesi, Sağlık Bilimleri Enstitüsü.

Neuman, W. L. (2012). Toplumsal Araştırma Yöntemleri: Nicel ve Nitel Yaklaşımlar I-II. Cilt (5. Basım). İstanbul: Yayın Odası.

Özdemir, M. (2010). Nitel Veri Analizi: Sosyal Bilimlerde Yöntembilim Sorunsalı Üzerine Bir Çalışma. Eskişehir Osmangazi Üniversitesi Sosyal Bilimler Dergisi, 11(1), 323-343.

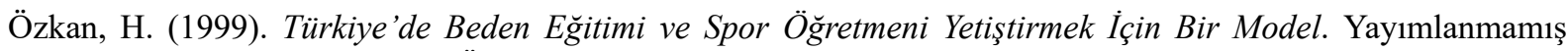
Doktora Tezi. Dokuz Eylül Üniversitesi, Eğitim Bilimleri Enstitüsü.

Özmen, H. (2004). Fen Öğretiminde Öğrenme Teorileri ve Teknoloji Destekli Yapılandırmacı (Constructivist) Öğrenme. The Turkish Online Journal of Educational Technology - TOJET, 3(1), 14.

Pehlivan, Z. (2001). Illköğretimde Beden Eğitimi Öğretmeni Yetiştirme. II. Ulusal Beden Eğitimi ve Spor Öğretmenliği Sempozyumu, 21-23 Aralık 2001 Uludağ Üniversitesi, Bursa

Power, Z., Campbell, M., Kilcoyne, P., Kitchener, H., \& Waterman, H. (2010). The Hyperemesis Impact of Symptoms Questionnaire: development and validation of a clinical tool. International journal of nursing studies, 47(1), 67-77. https://doi.org/10.1016/j.ijnurstu.2009.06.012

Sağlam, M., Özüdoğru, O. F., \& Çıray, F. (2011). Avrupa Birliği eğitim politikaları ve Türk Eğitim Sistemi’ne etkileri. Yüzüncü Yll Üniversitesi Eğitim Fakültesi Dergisi, 8(1), 87-109.

Spittle, M., \& Spittle, S. (2016). Content of curriculum in physical education teacher education: Expectations of undergraduate physical education students. AsiaPacific Journal of Teacher Education, 44(3), 257-273, https://doi.org/10.1080/1359866x.2015.1080813

Tinning, R. (2006). Theoretical orientations in physical education teacher education. In D. Kirk, D. Macdonald, \& M. O'Sullivan (Eds.), The handbook of physical education (pp. 369-385). London: Sage. https://doi.org/10.4135/9781848608009.n21

Titiz, O. (2005). Yeni Öğretim Sistemi. Zambak Yayınları.

Wuest, D. A., \& Bucher, C. A. (1999). Foundations of Physical Education and Sports (pp. 146-191). Boston: WCB.

Yıldırım, A., \& Şimşek, H. (2013). Sosyal bilimlerde nitel araştırma yöntemleri. Seçkin yayıncılık.

YÖK. (1998). Ĕgitim Fakültesi Öğretmen Yetiştirme Lisans Programları. Ankara, Yükseköğretim Kurulu Başkanlığı, Ankara.

YÖK. (2007). Eğitim Fakültesi Öğretmen Yetiştirme Lisans Programları. Yükseköğretim Kurulu Başkanlığı, Ankara. 


\section{Copyrights}

Copyright for this article is retained by the author(s), with first publication rights granted to the journal.

This is an open-access article distributed under the terms and conditions of the Creative Commons Attribution license (http://creativecommons.org/licenses/by/4.0/). 